\title{
Biological Monitoring Using Macroinvertebrates as Bioindicators of Water Quality of Maroaga Stream in the Maroaga Cave System, Presidente Figueiredo, Amazon, Brazil
}

\author{
Christiane Brito Uherek ${ }^{1,2}$ and Fernando Bernardo Pinto Gouveia ${ }^{1,3,4}$ \\ ${ }^{1}$ Escola Superior Batista do Amazonas, Rua Leonor Teles 153, 69057-510 Manaus, AM, Brazil \\ ${ }^{2}$ Department of Biological Sciences, University of Alberta, CW-405, Edmonton, AB, Canada T6G $2 E 9$ \\ ${ }^{3}$ Faculdade Literatus, Avenida Constantino Nery 3693, 69050-000 Manaus, AM, Brazil \\ ${ }^{4}$ Instituto Nacional de Pesquisas da Amazônia, Avenida André Araújo 2936, Petrópolis, 69067-375 Manaus, AM, Brazil
}

Correspondence should be addressed to Christiane Brito Uherek; uherek@ualberta.ca

Received 26 July 2013; Revised 1 December 2013; Accepted 25 December 2013; Published 17 February 2014

Academic Editor: L. M. Chu

Copyright (C) 2014 C. B. Uherek and F. B. Pinto Gouveia. This is an open access article distributed under the Creative Commons Attribution License, which permits unrestricted use, distribution, and reproduction in any medium, provided the original work is properly cited.

\begin{abstract}
Aquatic environments are being modified by anthropogenic activities regarding their biological, physical, and chemical conditions; even pristine aquatic ecosystems can be threatened. This study focused on the biological monitoring of Maroaga Stream-a first order stream located in an Environmental Protection Area in the Amazon using the Biological Monitoring Working Party (BMWP) Score System. The BMWP Score System revealed that the Maroaga Stream was a Class I stream (score of 138 points), indicating clean or not significantly altered water quality. The results suggest the adequate environmental conditions and ecological responses of the Maroaga Stream.
\end{abstract}

\section{Introduction}

The last few decades have witnessed increasing concerns about environmental problems produced by the anthropogenic degradation and misapplication of natural resources. Policies regarding the correct usage of water are extremely important because the availability of clean freshwater resources is essential for the maintenance of life throughout the world [1]. Improving our understanding of freshwater ecology is therefore very important not only because of its biological implications, but also because the proper management of freshwater is of practical interest to mankind [2].

Freshwater environments are subjected to increasing degradation. In addition to the extensive range of natural stresses encountered by organisms in their habitats, human activities can generate other environmental stresses [3]. Such harmful alteration, disruption, or destruction of freshwater environments could become irreversible, particularly in overpopulated developing countries such as Brazil [4].
In Brazil, concerns regarding the conservation of watersheds led to legislation that focused on the proper management of water resources [5]. However, Brazilian environmental laws and regulatory processes do not require biological evaluations of aquatic ecosystems [6]. Rather, water quality assessments are primarily focused on the analysis of physicochemical data [7]. As a result, macroinvertebrate indices have been developed recently for the evaluation of aquatic environments in Brazil, especially in southeastern Brazil [8]. Early on, Callisto and Esteves [9] investigated the functional feeding groups of benthic macroinvertebrate communities in Central Amazon. More significantly, Buss et al. [6] presented the conceptual basis for biomonitoring and indicated that its application in Brazil would help watershed managers and policy-makers to reduce costs, increase the efficiency of analyses, and simplify the results. Subsequently, Buss [7] proposed the development of a biotic index for volunteer monitoring and assessment of stream water quality and Monteiro et al. [10] evaluated the environmental health of 
waters in Central Brazil using BMWP Score System. More recently, Couceiro et al. [8] proposed an index to evaluate biological condition of streams in the Central Amazon.

Due to on-going threats to aquatic ecosystems in the Amazon, a better understanding of Amazonian biodiversity could lead to specific conservation studies of these ecosystems [11]. Streams in the Central Amazon are under intense anthropogenic pressure as a result of increasing economic development in the region. In the Amazon there is no ongoing monitoring of environmental health of aquatic environments; as a result, environmental changes are generally perceived only when streams are highly altered [8]. The Amazonian environment thus needs a rapid assessment that involves an easy-to-use sampling and analysis approach; as a bioassay, the BWMP is easy to apply and has greatly reduced costs when compared to physicochemical analyses, which can require sample processing in laboratories outside of the Amazon. Therefore in the face of intense anthropogenic pressure from deforestation, the use of natural resources and disorderly growth of urban areas, all of which contribute to the degradation of streams [8], the use of the BMWP as a rapid bioassessment that requires limited effort can produce scientifically valid and repeatable results of environmental monitoring [1]. Furthermore, the BMWP can help establish an environmental baseline, since data for many streams are sparse or nonexistent [12].

Freshwater environments can be monitored by physical, chemical, and biological parameters. Biological parameters integrate information over longer periods of time and better represent the responses of aquatic habitats [13], making biotic monitoring indices excellent tools for the sustainable management of water resources [8]. Literature reviews of running water assessments based on biological indicators identify at least 100 indices developed over the past ten years, of which about $60 \%$ are based on macroinvertebrates [14], more than for any other group of freshwater organisms [15]. Despite a wide range of adaptations, certain macroinvertebrate taxa can serve as indicators of environmental conditions [16]. Several groups of aquatic insects are among the organisms that are extensively used for monitoring aquatic ecosystems [17]; the first step to use these organisms as an environmental monitoring tool is the correct taxonomic identification [11].

Aquatic insects and other organisms in freshwater systems are also monitored to gauge subtle and profound effects that changes in water quality can have on aquatic life. Biomonitoring of this sort has some decided advantages when compared to other types of analysis, for example, chemical analysis. Benthic insects and other invertebrates maintain relatively fixed positions in the aquatic environment. Thus, the freshwater invertebrates can reflect both short and long term shifts in water quality. Chemical analysis and/or animals that have great mobility, such as fishes, tend to present snapshots of the period when samples were taken [18].

Some freshwater invertebrates are very sensitive to stresses produced by pollution, habitat modification, or severe natural events, while others are more tolerant [15]. Benthic macroinvertebrates, such as annelids, crustaceans, Mollusca, and adults and juveniles of insects, have biological and ecological characteristics that justify their wide use in biomonitoring studies; they are used in a variety of ways, including toxicological testing in the laboratory and field, measurements of change in population numbers, community composition, or ecosystem functioning [19, 20]. Macroinvertebrates are widely used as bioindicators in many developed countries and are included in national and technical standards of water quality monitoring in Europe. In Brazil, their use is still very limited [21].

There is a clear link between the health of the Amazon and the health of the planet. The Amazonian landscape contains one in ten known species on Earth, 560 million hectares of dense forests, and 4,100 winding rivers [22, 23]. Presidente Figueiredo is a rich natural landscape, highlighted by its unique geomorphological aspects, for example, valleys, rivers, lakes, streams, waterfalls, caves, and caverns, and consequently attracts a large number of visitors. In particular, the Maroaga Cave is one of the most visited sites in the Central Amazon and is under serious degradation [24]. In addition the cave has another unique feature: a first order stream that has its spring-source inside the cave, with an underground channel until it flows outside into the forest [25].

The goal of the present study was to assess the environmental health of Maroaga Stream, a first order watercourse, located in an Environmental Protection Area of Presidente Figueiredo, Amazon, Brazil, using aquatic macroinvertebrates as bioindicators.

\section{Materials and Methods}

2.1. Study Area. The study area is located in Presidente Figueiredo, Amazon, Brazil $\left(02^{\circ} 02^{\prime} 58,7^{\prime \prime} \mathrm{S} 59^{\circ} 58^{\prime} 22^{\prime \prime} \mathrm{W}\right)$, north of Manaus (Figure 1). This Environmental Protection Area has 374,700 hectares and incorporates 33 native communities, covering 14,73\% of the area. Presidente Figueiredo is well known for its unique geomorphological aspects, for example, cave systems and waterfalls. The main economic activities are livestock rearing and agriculture (including cupuaçu, i.e., Theobroma grandiflorum, farming), as well as mineral and plant exploitation. The unique natural features have also made tourism a growing industry in the region [25].

Development of the Maroaga Cave system (Figure 2) started approximately 400,000 years ago when the watersheds reached higher levels and when glaciations occurred in the Amazon. Its origin is related to chemical weathering, especially hydrolysis, and mechanical effects of water current. The Maroaga Cave is an important archaeological site with artifacts of several native tribes, probably from the WaimiriAtroari [26].

Maroaga Stream (Figure 3) has its spring-source on top of a sandstone plateau. The channel flows to the edge of the plateau and then down about 30 meters until it reaches the plateau's base. In some places there are geological and topographical features directing the stream into cavities resulting in an underground section [25].

2.2. Methodology. Macroinvertebrates constitute a heterogeneous assemblage of animal taxa, many of which are sedentary, and some have relatively long life spans. Many methods of data analysis, including pollution indices and diversity 


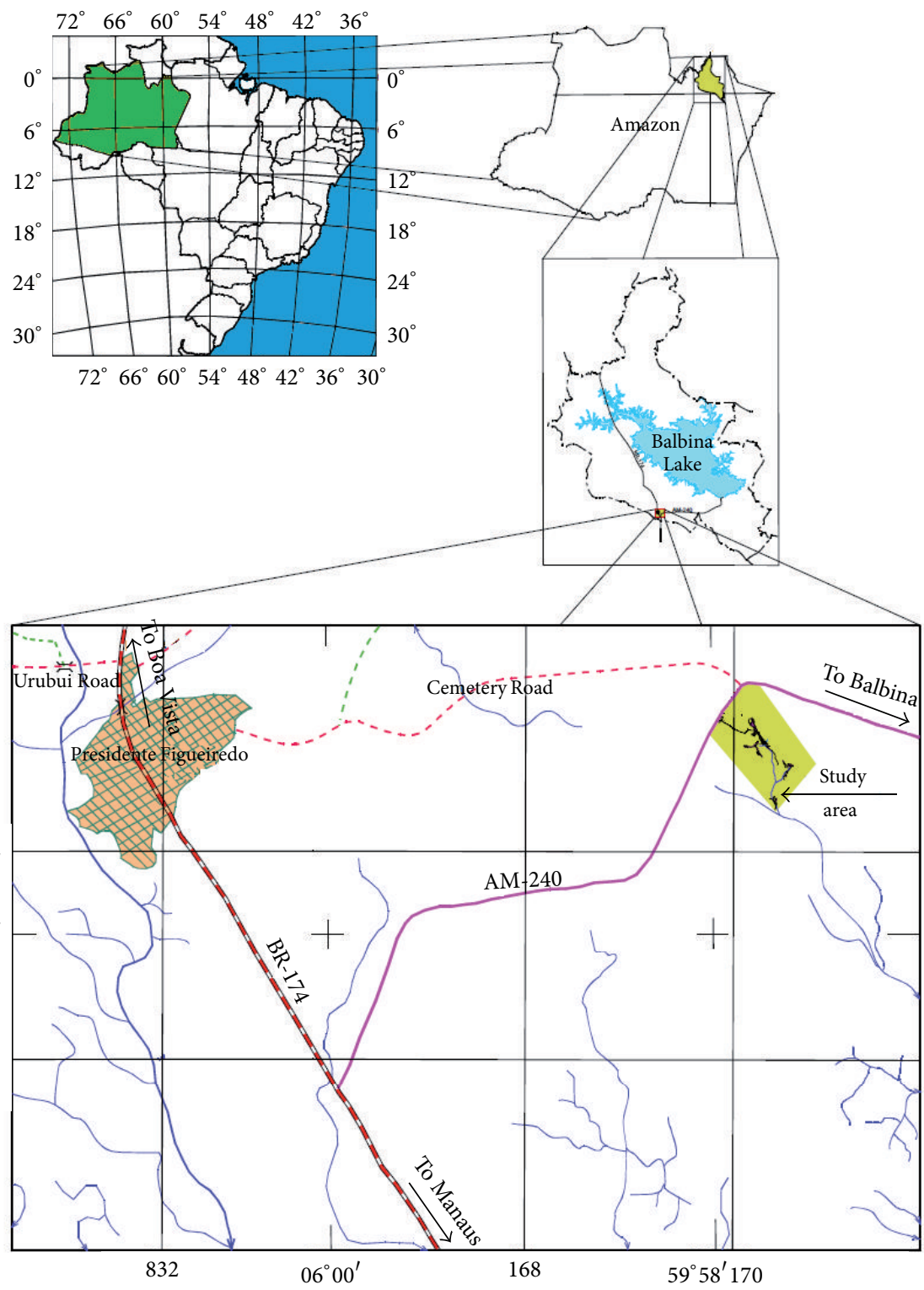

FIgURE 1: Study area (adapted from Amazonastur/Proecotur, 2004).

indices, have been devised for the group. The widespread, almost universal, use of these techniques testifies to their value in water quality management [3].

The index used here to assess the environmental quality of the Maroaga Stream based on macroinvertebrates was the BMWP Score System, created by Hellawell [27] and adapted by Alba-Tercedor and Sánchez Ortega [28].

The BMWP Score System is an index requiring limited taxonomic precision, thus saving time and economic resources. Being simple and easy to apply, the BMWP Score System requires taxonomic identification of the invertebrates only to the family level but can accept order or even class for some groups. This index summarizes presence/absence and tolerance of the taxa present at a site. Several physical and chemical parameters that are correlated significantly with benthic community structure are used to predict unimpacted benthic community structure [20]. Alba-Tercedor and Sánchez Ortega [28] modified the original BMWP table, increasing the number of taxa but preserving the original scores. Alba-Tercedor [29] further updated the taxonomic groups and scores (Table 2) as well as the category and interpretation of results (Table 1), based on Armitage et al. [30].

The overall BMWP score evaluation is the sum of all scores of each taxon (class, order, or family) present in a study site (Table 1). According to Alba-Tercedor [29], the total score for a site indicates water quality categories ranging from "good" to "very critical" (Table 1). Each taxon receives a score that reflects its susceptibility to pollution; that is, pollution-intolerant taxa receive high scores, whereas pollution-tolerant taxa are given low scores. 


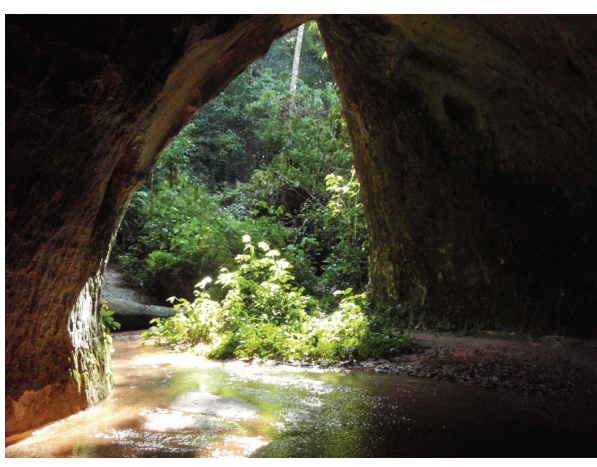

(a)

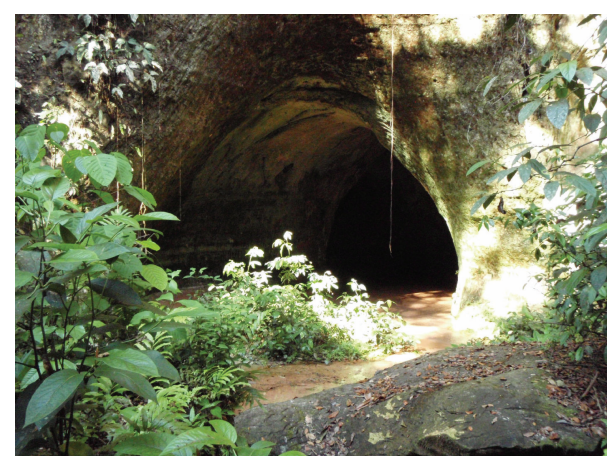

(b)

FIgUre 2: Maroaga Cave entrance ((a) left: internal view; (b) right: external view).

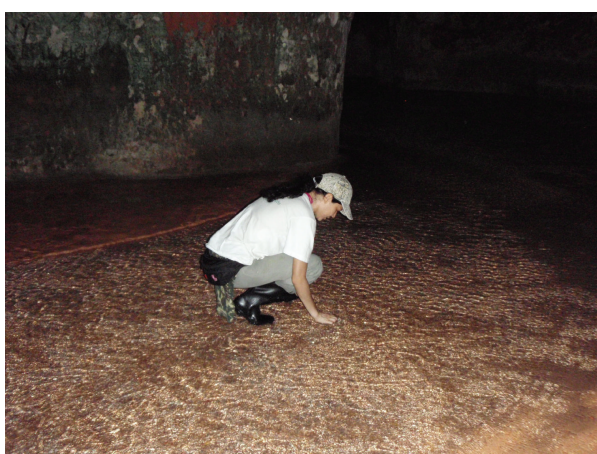

(a)

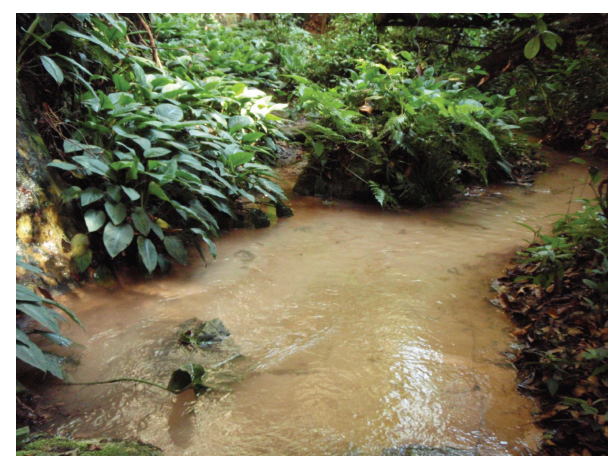

(b)

FIgURe 3: Maroaga Stream ((a) left: internal view; (b) right: external view).

Initially, the BMWP table was based on invertebrates found in Iberian Peninsula watersheds. Therefore, adaptations were needed for proper use in the Amazon. These readjustments were based on the studies of Bobot et al. [31], Bobot et al. [32], Callisto and Esteves [9], Couceiro et al. [33], and Junqueira et al. [21]. In addition, taxa that were not included in the original table [29] received a score of 1 , and taxa not originally included but whose order or class was listed received the lowest score assigned to the equivalent order or class (Table 2).

2.3. Sampling Techniques and Data Analysis. On March 29, 2008, the aquatic macroinvertebrates were collected at 12 sampling locations, the first point starting $100 \mathrm{~m}$ downstream of the entrance of the Maroaga Cave and proceeding downstream at $25 \mathrm{~m}$ intervals. All sampling stations were located where the stream was a first order stream.

Macroinvertebrates were collected for a period of 15 minutes by manual collection, that is, examining the substrate, fines, sand, gravel, cobbles, boulders, leaves, and submerged branches, from riffles and pools at each location. Samples were collected using kick nets and/or manually (kick samples). In riffles the kick net was held vertically on the stream bed and an area of the substratum was disturbed by hands; stream flow carried the sample into the net. In pools, the stream bed was disturbed vigorously by hand and the dislodged sample was pushed into the net. Each sample was placed into a white plastic tray with dimensions of $450 \times 300 \times$ $80 \mathrm{~mm}$ and macroinvertebrates were separated from macrophytes or sediments using forceps and preserved in 96\% ethanol. Identification was to the lowest practical taxonomic level using the identification keys of Merritt and Cummins [34] and McCafferty [18]. The presence of a taxon from any one of the 12 locations was used to calculate the BMWP score.

\section{Results and Discussion}

We collected 253 individuals. They belonged to 25 major taxonomic groups (Table 3 ). After identification, BMWP scores were assigned to each taxon (Tables 2 and 3 ) and the sum (138 points) was calculated. According to the BMWP classification method as adapted by Armitage et al. [30] and Alba-Tercedor [29] our results indicated that the environmental health of the Maroaga Stream fell into the category of "good" which can be interpreted as "clean or not significantly altered" aquatic environment, not reaching the level of very clean water.

Based on our results, the Maroaga Stream could not be considered as having "very clean" water (score $>150$ ), despite being located in an Environmental Protection Area. This may be due to the fact that the Maroaga Stream flows through the interior of the Maroaga Cave, which is inhabited by a considerable number of bats. Bat waste (guano) is deposited on Maroaga Cave floor and part of that guano enters the 
TABLE 1: BMWP classes, scores, categories, and result interpretation (adapted from Armitage et al., 1983 [30], and Alba-Tercedor, 1996 [29]).

\begin{tabular}{lccc}
\hline Class & BWMP score & Category & Interpretation \\
\hline I & $>150$ & Good & Very clean water \\
& $101-150$ & Acceptable & Clean or not significantly altered \\
II & $61-100$ & Questionable & Clean but slightly impacted \\
III & $36-60$ & Critical & Polluted or impacted \\
IV & $15-35$ & Very critical & Heavily polluted \\
V & $<15$ & & \\
\hline
\end{tabular}

TABLE 2: BMWP taxa scores: class, order, or family (adapted from Alba-Tercedor, 1996 [29]).

\begin{tabular}{|c|c|}
\hline Taxa & Score \\
\hline $\begin{array}{l}\text { Ephemeroptera: Leptophlebiidae, Leptohyphidae } \\
\text { Plecoptera: Perlidae } \\
\text { Trichoptera: Brachycentridae, Leptoceridae, Odontoceridae, and Sericostomatidae }\end{array}$ & 10 \\
\hline $\begin{array}{l}\text { Odonata: Coenagrionidae, Calopterygidae, Cordulegastridae, Gomphidae, and Libellulidae } \\
\text { Trichoptera: Calamoceratidae, Glossosomatidade, Philopotamidae, and Psychomyiidae }\end{array}$ & 8 \\
\hline $\begin{array}{l}\text { Plecoptera: Nemouridae } \\
\text { Trichoptera: Polycentropodidae }\end{array}$ & 7 \\
\hline $\begin{array}{l}\text { Crustacea } \\
\text { Trichoptera: Hydrobiosidae, Hydroptilidae }\end{array}$ & 6 \\
\hline $\begin{array}{l}\text { Coleoptera: Elmidae, Dryopidae } \\
\text { Diptera: Simuliidae, Tipulidae } \\
\text { Ephemeroptera: Euthyplociidae, Polymitarcidae } \\
\text { Platyhelminthes } \\
\text { Trichoptera: Helicopsychidae, Hydropsychidae }\end{array}$ & 5 \\
\hline $\begin{array}{l}\text { Arachnida: Hydracarina } \\
\text { Coleoptera: Chrysomelidae, Curculionidae, and Haliplidae } \\
\text { Diptera: Anthomyiidae, Ceratopogonidae, Chaoboridae, Dixidae, Dolichopodidae, } \\
\text { Empididae, Limoniidae, Psychodidae, Stratiomyidae, and Tabanidae } \\
\text { Ephemeroptera: Baetidae, Caenidae } \\
\text { Megaloptera: Corydalidae, Sialidae }\end{array}$ & 4 \\
\hline $\begin{array}{l}\text { Annelida: Hirudinea } \\
\text { Coleoptera: Dytiscidae, Gyrinidae, Helodidae, Hydrophilidae, and Noteridae } \\
\text { Hemiptera: Belostomatidae, Corixidae, Gerridae, Hydrometridae, } \\
\text { Mesoveliidae, Naucoridae, Nepidae, Notonectidae, Pleidae, and Veliidae } \\
\text { Mollusca }\end{array}$ & 3 \\
\hline Diptera: Chironomidae, Culicidae, Ephydridae, Muscidae, and Thaumaleidae & 2 \\
\hline $\begin{array}{l}\text { Annelida: Oligochaeta } \\
\text { Blattaria: Blattidae } \\
\text { Diptera: Sciomyzidae, Syrphidae, and Rhagionidae } \\
\text { Lepidoptera }\end{array}$ & 1 \\
\hline
\end{tabular}

Maroaga Stream. The addition of the guano to the stream water likely altered the physicochemical properties of the water and, in turn, affected the macroinvertebrate community.

Nonetheless our results suggest that the Environmental Protection Areas policies are having a positive effect to ensure the conservation of the region. However, given the continued use of the site by the general public, further environmental control may be required to safeguard the environmental quality of the Maroaga Stream.

Nevertheless, given the increase in the number of urban settlements in Presidente Figueiredo in the recent years as well as new residential areas near to environmental conservation and protection areas, other watercourses located in these areas should also be monitored to assess their environmental health. 
TABLE 3: Aquatic macroinvertebrates present at each sampling location.

\begin{tabular}{|c|c|c|c|c|c|c|c|c|c|c|c|c|c|}
\hline \multirow{2}{*}{ Invertebrates } & \multicolumn{12}{|c|}{ Sampling locations } & \multirow{2}{*}{ Points } \\
\hline & 1 & 2 & 3 & 4 & 5 & 6 & 7 & 8 & 9 & 10 & 11 & 12 & \\
\hline Blattaria: Blattidae & + & & & & + & & & & & & & & 1 \\
\hline Coleoptera: Curculionidae & & + & & & & & & & & & & & 4 \\
\hline Coleoptera: Helodidae & & & & & + & & & & & & & & 3 \\
\hline Crustacea & & & & & & & & & & + & + & & 6 \\
\hline Diptera: Chironomidae & & & & & & & & & & & & + & 2 \\
\hline Ephemeroptera: Baetidae & & + & & & & & & & & & & & 4 \\
\hline Hemiptera: Gerridae & & & & & & & & + & & & & & 3 \\
\hline Hemiptera: Naucoridae & + & & + & + & & & + & + & & & & & 3 \\
\hline Hemiptera: Veliidae & + & & & & & & & & & & & & 3 \\
\hline Hydracarina: Aranae & & & & & + & & & & & & & & 4 \\
\hline Lepidoptera & & + & & + & & + & + & & + & & + & + & 1 \\
\hline Megaloptera: Corydalidae & + & & + & + & + & + & + & + & + & + & + & + & 4 \\
\hline Odonata: Calopterygidae & & & & & & & + & & & & & & 8 \\
\hline Odonata: Coenagrionidae & + & & & & + & & & & & & & & 8 \\
\hline Odonata: Cordulegastridae & & & & & & & & & & & & + & 8 \\
\hline Odonata: Gomphidae & & + & & & + & + & & & & & & & 8 \\
\hline Planaria & + & + & + & & & & + & + & & & & + & 5 \\
\hline Plecoptera: Perlidae & + & + & + & + & + & + & + & + & + & & + & + & 10 \\
\hline Trichoptera: Calamoceratidae & & + & + & + & + & & & & & + & & + & 8 \\
\hline Trichoptera: Helicopsychidae & & & & & & & & + & + & & & & 5 \\
\hline Trichoptera: Hydropsychidae & + & + & + & + & + & + & + & + & + & & & + & 5 \\
\hline Trichoptera: Leptoceridae & & & & & & & + & & & & & & 10 \\
\hline Trichoptera: Odontoceridae & & & + & & & & + & & & & & & 10 \\
\hline Trichoptera: Philopotamidae & & + & + & & & + & & + & + & & + & & 8 \\
\hline Trichoptera: Polycentropodidae & & + & & & & & & & & & & & 7 \\
\hline & & & & To & & & & & & & & & 138 \\
\hline
\end{tabular}

\section{Conclusion}

Our study, using the BMWP, indicated that the Maroaga Stream is characterized by a healthy macroinvertebrate community and thus with a "clean" environmental quality. The use of macroinvertebrates as bioindicators confirms their importance as a valuable monitoring tool in assessing freshwater ecosystems, highlighting their easy-to-use nature when surveying and assessing the health of watersheds in Amazonian environments. Bearing in mind the ecological and economical aspects of satisfactory environmental assessment, this approach has several features that can facilitate better water resource management; the BMWP Score System is easy to apply and has greatly reduced costs compared to physical and chemical analyses, many of which require transport of water samples to laboratories outside of the Amazon. Biological monitoring using macroinvertebrates is thus a suitable option that should be considered to meet the needs of Amazon watershed management and the taxa used in this study could help improve the evaluation of water quality in the streams in the Amazon.

\section{Conflict of Interests}

The authors declare that there is no conflict of interests regarding the publication of this paper.

\section{References}

[1] S. L. Loeb and A. Spacie, Biological Monitoring of Aquatic Systems, Lewis Publishers, Boca Raton, Fla, USA, 1993.

[2] M. Bates, The Forest and the Sea, Time Incorporated Book Division, New York, NY, USA, 1960.

[3] J. M. Hellawell, Biological Indicators of Freshwater Pollution and Environmental Management, Elsevier Applied Science, New York, NY, USA, 1986.

[4] A. C. Rebouças, "Água doce no mundo e no Brasil," in Águas doces no Brasil: uso e conservação, A. C. Rebouças, B. Braga, and J. G. Tundisi, Eds., pp. 1-61, Escrituras Editora, São Paulo, Brazil, 1999.

[5] A. P. Magalhães Júnior, Indicadores ambientais e recursos hídricos: realidade e perspectivas para o Brasil a partir da experiência francesa, Bertrand Brasil, Rio de Janeiro, Brazil, 2007. 
[6] D. F. Buss, D. F. Baptista, and J. L. Nessimian, "Bases conceituais para a aplicação de biomonitoramento em programas de avaliação da qualidade da água de rios," Cadernos de Saúde Pública, vol. 19, pp. 465-473, 2003.

[7] D. F. Buss, "Desenvolvimento de um índice biológico para uso de voluntários na avaliação da qualidade da água de rios," Oecologia Brasiliensis, vol. 12, pp. 520-530, 2008.

[8] S. R. M. Couceiro, N. Hamada, B. R. Forsberg, T. P. Pimentel, and S. L. B. Luz, "A macroinvertebrate multimetric index to evaluate the biological condition of streams in the Central Amazon region of Brazil," Ecological Indicators, vol. 18, pp. 118125, 2012.

[9] M. Callisto and F. A. Esteves, "Categorização funcional dos macroinvertebrados bentônicos em quatro ecossistemas lóticos sob influência das atividades de uma mineração de bauxita na Amazônia Central (Brasil)," Oecologia Brasiliensis, vol. 5, pp. 223-234, 1998.

[10] T. R. Monteiro, L. G. Oliveira, and B. S. Godoy, "Biomonitoramento da qualidade de água utilizando macroinvertebrados bentônicos: adaptação do índice biótico BMWP à Bacia do Rio Meia Ponte-GO," Oecologia Brasiliensis, vol. 12, pp. 553-563, 2008.

[11] N. Hamada and R. L. Ferreira-Keppler, Guia ilustrado de insetos aquáticos e semiaquáticos da Reserva Florestal Ducke, Editora da Universidade Federal do Amazonas, Manaus, Brazil, 2012.

[12] K. Watson-Ferguson, Guide to Aquatic Insects and Crustaceans-The Izaak Walton League of America, Stackpole Books, Mechanicsburg, Penn, USA, 2006.

[13] D. Navas-Pereira and R. M. Henrique, "Aplicação de índices biológicos numéricos na avaliação da qualidade ambiental," Revista Brasileira de Biologia, vol. 56, pp. 441-450, 1996.

[14] I. Czerniawska-Kusza, "Comparing modified biological monitoring working party score system and several biological indices based on macroinvertebrates for water-quality assessment," Limnologica, vol. 35, no. 3, pp. 169-176, 2005.

[15] J. R. Voshell, A Guide to Common Freshwater Invertebrates of North America, The McDonald and Woodward Publishing, Granville, NY, USA, 2002.

[16] E. P. Odum, Ecology-Modern Biology Series, Holt, Rinehart and Winston, Austin, Tex, USA, 1963.

[17] T. P. Moulton, "Saúde e integridade do ecossistema e o papel dos insetos aquáticos," in Ecologia de insetos aquáticos. Séries Oecologia Brasiliensis, J. L. Nessimian and A. L. Carvalho, Eds., vol. 5, pp. 281-298, PPGE-UFRJ, 1998.

[18] W. P. McCafferty, Aquatic Entomology: The Fisherman's and Ecologist's Illustrated Guide to Insects and Their Relatives, Jones and Bartlett Publishers, Boston, Mass, USA, 1998.

[19] J. L. Metcalfe, "Biological water quality assessment of running waters based on macroinvertebrate communities: history and present status in Europe," Environmental Pollution, vol. 60, no. 1-2, pp. 101-139, 1989.

[20] D. M. Rosenberg and V. H. Resh, Freshwater Biomonitoring and Benthic Macroinvertebrates, Chappman \& Hall, New York, NY, USA, 1993.

[21] M. V. Junqueira, M. C. Amarante, and C. F. S. Dias, "Biomonitoramento da qualidade das águas da bacia do Alto Rio das Velhas através de macroinvertebrados," Acta Limnológica Brasileira, vol. 12, pp. 73-87, 2000.

[22] WWF, Living Planet Report 2012: Biodiversity, Biocapacity and Better Choices, World Wide Fund for Nature, Zurich, Switzerland, 2012.
[23] WWF, Amazon Headwaters Initiative Monitoring and Evaluation Report: The Contributions of Three Conservation Strategies to Protected Area Consolidation, World Wide Fund for Nature, Zurich, Switzerland, 2012.

[24] E. M. Gadelha and J. D. Alecrim, “Turismo: impactos nos aspectos geomorfológicos da área de proteção ambiental Presidente Figueiredo Caverna do Maroaga-AM," Caderno Virtual do Turismo, vol. 6, pp. 19-24, 2006.

[25] Amazonastur/Proecotur, "Plano de Manejo Espeleológico e Projetos Específicos de Infra-Estrutura e Sinalização da Caverna do Maroaga, Presidente Figueiredo/AM," Ecossistema Consultoria Ambiental, Presidente Figueiredo, 2004.

[26] I. Farias, Presidente Figueiredo: Terra de Cavernas e Cachoeiras Virgens, pp. 50-52, Revista Amazônia em Foco, Manaus, Brazil, 1989.

[27] J. M. Hellawell, Biological Surveillance of Rivers, Water Research Center, Stevenage, UK, 1978.

[28] J. Alba-Tercedor and A. Sánchez Ortega, "Un método rápido y simple para evaluar la calidade biológica de las aguas corrientes basado en el metodo de Hellawell," Limnetica, vol. 4, pp. 51-56, 1988.

[29] J. Alba-Tercedor, "Macroinvertebrados acuaticos e calidad de las aguas de los rios," in IV Simposio del Agua en Andalucía (SIAGA '96), vol. 2, pp. 203-213, Almeria, Spain, 1996.

[30] P. D. Armitage, D. Moss, J. F. Wright, and M. T. Furse, "The performance of a new biological water quality score system based on macroinvertebrates over a wide range of unpolluted running-water sites," Water Research, vol. 17, no. 3, pp. 333-347, 1983.

[31] T. E. Bobot, N. Hamada, and R. L. M. Ferreira, "Entomofauna de Igarapés na Região de Presidente Figueiredo, Amazonas, Brasil," in VIII Jornada de Iniciação Científica do INPA/PIBIC, pp. 7780, Manaus, Brazil, July 1998.

[32] T. E. Bobot, N. Hamada, and A. M. O. Pes, "Estrutura da comunidade de insetos aquáticos baseados na categorização funcional do hábito alimentar em Presidente Figueiredo, Amazonas, Brasil," in X Jornada de Iniciação Científica do INPA/PIBIC, pp. 23-25, Manaus, Brazil, July 2000.

[33] S. M. Couceiro, N. Hamada, and R. L. M. Ferreira, "Estrutura da comunidade da entomofauna em igarapés sob a influência do Rio Negro em Manaus, Amazonas, como subsídio para avaliação do impacto ambiental," in XI Jornada de Iniciação Científica do INPA/PIBIC, pp. 28-29, Manaus, Brazil, July 2001.

[34] R. W. Merritt and K. W. Cummins, An Introduction to the Aquatic Insects of North America, Kendall Hunt, Dubuque, Iowa, USA, 3rd edition, 1996. 

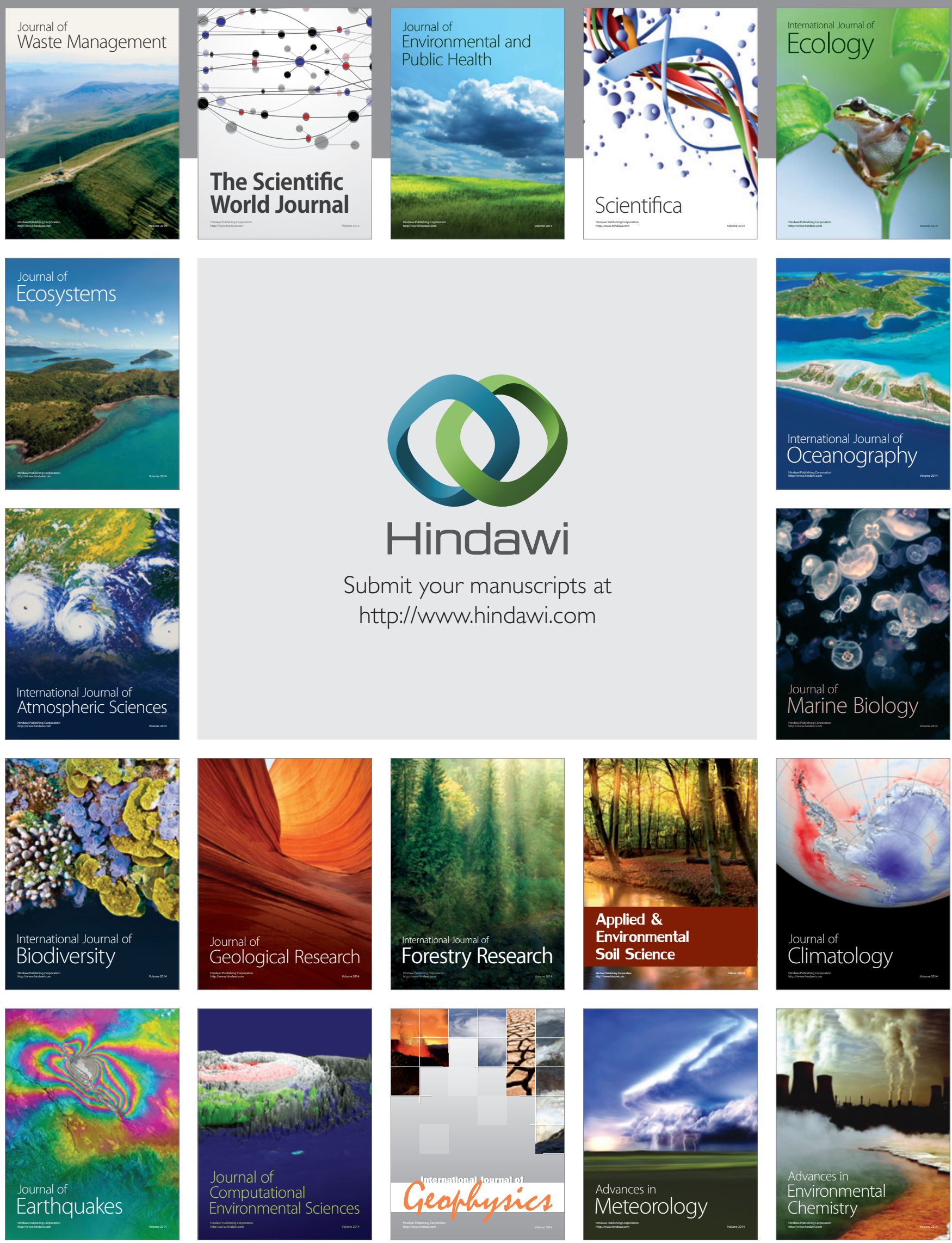